\title{
Acinetobacter /woffii Septicemia in a Newborn
}

\author{
Yenidoğan Bir Bebekte Acinetobacter Iwoffii sepsisi
}

\author{
๑Saime Sündüs Uygun', Gülsüm Alkan² \\ 'Selcuk University School of Medicine Department of Pediatrics, Division of Neonatology, Konya, Turkey \\ ${ }^{2}$ Selcuk University School of Medicine Department of Pediatrics, Division of Pediatric Infectious Diseases, Konya, Turkey
}

\begin{abstract}
Acinetobacter Iwoffii is gram-negative coccobacillus which is seen as a normal flora of the oropharynx and skin of the healthy individuals. It is a potential opportunistic pathogen in patients with impaired immune systems, and can cause of healthcare associated infections like septicemia. A. Iwoffii infection is increasing particularly in premature and very low-birth weight neonates. Here, we present a case of a low birth weight neonate with $A$. Iwoffii infection who was successfully treated.
\end{abstract}

Keywords: Acinetobacter /woffii, septicemia, NICU

\section{INTRODUCTION}

Acinetobacter is an aerobic, non-fermentative, immotile, gram negative bacillus, which is widespread in nature. It has been identified as a cause of healthcare associated infections, especially in the colonization and infection in immunocompromised patients as an opportunistic pathogen $(1,2)$. However, a limited number of cases of infection caused by Acinetobacter Iwoffii has been reported, most of them are central intravascular catheterrelated blood stream infections or bacteremia. On the other hand, community-acquired infections associated with Acinetobacter Iwoffii such as pneumonia, meningitis, urinary tract infection, skin and wound infection and acute gastroenteritis were also reported (3). This report presents the case of a low birth weight neonate with multidrug-resistant $A$. Iwoffii infection.

\section{ÖZ}

Acinetobacter/woffiisağlıklı bireylerin cilt ve orofarenksinde flora üyesi olarak saptanabilen bir gram-negatif kokobasildir. İmmün baskılanmış kişilerde fırsatçı patojen olarak septisemi gibi sağlık bakımı ilişkili enfeksiyonlara sebep olabilir. Prematüre ve düşük doğum ağırlıklı bebeklerde $A$. ıwoffii enfeksiyon sıklığı artmaktadır. Bu vaka sunumunda, düşük doğum ağırlıklı bir bebekte başarı ile tedavi edilmiş A. Iwoffii enfeksiyonunu sunmak istiyoruz.

Anahtar kelimeler: Acinetobacter/woffii, sepsis, yenidoğan yoğun bakım ünitesi

\section{CASE REPORT}

A male neonate was born at 26 week because of maternal preeclampsia. The mother had a history of chorioamnionitis. He was intubated due to respiratory failure. Ampicillin, amikacin treatment and fluconazole prophylaxis were started due to suspicion of early onset septicemia. Umbilical artery and vein catheters were inserted at the first day of life. The blood cultures, taken at the admission to neonatal intensive care unit (NICU), were negative. Ligation of ductus arteriosus was performed at seventh day of life. After surgery his vital signs deteriorated and abdominal distension developed. Sepsis was considered due to gastric residues, abdominal distention, and prolongation of capillary filling. Because of worsening clinical status, laboratory tests and blood cultures were repeated. The laboratory data were as 
follows: WBC $32,200 / \mathrm{mm}^{3}$, neutrophils 24,700 (76\%); lymphocytes 1,300 (4\%); monocyte 5900 (18\%); hemoglobin $11 \mathrm{~g} / \mathrm{dL}$; platelets $55,000 / \mathrm{mm}^{3} ; \mathrm{mm} / \mathrm{h}$; C-reactive protein $84 \mathrm{mg} / \mathrm{dL}$; procalcitonin was $4.1 \mathrm{ng} /$ $\mathrm{mL}$. Metabolic acidosis was detected. Lumbar puncture was not performed, because of poor general condition and thrombocytopenia. Air around the intestinal wall was detected on abdominal radiography. He underwent surgery for perforated necrotizing enterocolitis. Broad spectrum antibiotics (meropenem, teicoplanin and fluconazole) were started immediately for suspicion of healthcare associated infection. Central vascular catheter was removed. The result of the blood culture was reported as $A$. Iwoffii. The microorganism was resistant to penicillin $G$, cefotaxime, ceftazidime, gentamicin, amikacin, cefepime and sensitive to meropenem (Minimal inhibitor concentration values: $<0.5$ ). Five days later his clinical findings improved, and inflammation markers returned to normal levels. Control blood culture was negative and meropenem treatment was completed to two weeks.

\section{DISCUSSION}

Acinetobacter Iwoffii, is an aerobic and gramnegative bacillus and recognized as normal flora of the skin, oropharynx, and perineum of healthy individuals. It has been previously reported that $A$. Iwoffii is found in environmental sources, particularly on the hands of nursing staff. It was associated with healthcare associated infections, particularly in immunocompromised hosts (4). Most of cases of $A$. Iwoffii bacteraemia are associated with central vascular catheter (2).

Factors such as longer stay in hospital, intensive care unit, and burn units, major surgical procedures, neutropenia, underlying chronic diseases, and previous antibiotic use are predisposing factors for Acinetobacter infections (5). Prematurity is thought to be associated with disseminated disease because of the immaturity of the immune system (6). Our patient was premature and extremely low birth weight infant. He was undergone ductal ligation and perforated necrotizing enterocolitis repair. He also had umbilical catheter. All these factors contributed to the development of $A$. Iwoffii septicemia.

The infections due to Acinetobacter spp. are often extremely difficult for clinicians to treat, because of rapid antimicrobial resistance development to all currently available antimicrobial agents like aminoglycosides, fluoroquinolones, ureidopenicillins and third generation cephalosporins (7). Carbapenems are the most effective antibiotics against these agents, while colistin can be used against carbapenem resistant Acinetobacterspp. on rare occasion (8).
Increasing rates of Acinetobacter spp are reported in $\mathrm{NICUs}$. Judicious and timely antibiotic treatment is one of the important keys in controlling multi-drug resistant Acinetobacterinfections (9). In the selection of empirical antibiotic treatment for healthcare associated neonatal sepsis cases, the resistance status of each unit should be considered.

\section{ETHICAL DECLARATIONS}

Informed Consent: Written informed consent was obtained from all participants who participated in this study.

Referee Evaluation Process: Externally peer-reviewed. Conflict of Interest Statement: The authors have no conflicts of interest to declare.

Financial Disclosure: The authors declared that this study has received no financial support.

Author Contributions: All of the authors declare that they have all participated in the design, execution, and analysis of the paper, and that they have approved the final version.

\section{KAYKANLAR}

1. Regalado NG, Martin G, Antony SJ. Acinetobacter Iwoffii: bacteremia associated with acute gastroenteritis. Travel Med Infect Dis. 2009;7:316-17.

2. Mori T, Nakazato T, Yamazaki R, Ikeda Y, Okamoto S. Acinetobacter Iwoffii septicemia associated with a peripheral intravascular catheter. Intern Med. 2006;45(12):803-804.

3. Huddam B, Koçak G, Azak A, Duranay M. Acinetobacter Iwoffii peritonitis in a patient receiving continuous ambulatory peritoneal dialysis. Ther Apher Dial. 2013;17:117-119.

4. Starakis I, Blikas A, Siagris D, Marangos M, Karatza C, Bassaris H. Prosthetic valve endocarditis caused by Acinetobacter Iwoffi: a case report and review. Cardiol Rev. 2006;14:45-49.

5. Tega L, Raieta K, Ottaviani D, Russo GL, Blanco G, Carraturo A. Catheter-related bacteremia and multidrug-resistant Acinetobacter /woffii. Emerg Infect Dis. 2007;13:355-356.

6. Nakwan N, Wannaro J, Nakwan N. Multidrug-resistant Acinetobacter Iwoffii infection in neonatal intensive care units. Research and Reports in Neonatology. 2011;1:1-4

7. Singla P, Sikka R, Deeep A, Gagneja D, Chaudhary U. Coproduction of ESBL and AmpC $\beta$-Lactamases in Clinical Isolates of A. baumannii and $A$. Iwoffii in a Tertiary Care Hospital From Northern India. J Clin Diagn Res. 2014;8:16-19.

8. Murray Clinton K, Hospentahl Duane R. Acinetobacterinfection in the ICU. Crit Care Clin . 2008;24:237-248.

9. Mittal S, Sharma M, Yadav A, Bala K, Chaudhary U. Acinetobacter Iwoffii an emerging pathogen in neonatal ICU. Infect Disord Drug Targets. 2015;15:184-188. 